\title{
Adoption in the service of child protection. An international interdisciplinary
}

$$
\text { perspective }
$$

$\begin{array}{ll}\text { Jesús Palacios }{ }^{1} & \text { Laura Martínez-Mora }{ }^{2} \\ \text { University of Seville, Spain } & \text { The Hague Conference on Private } \\ \text { Salomé Adroher } & \begin{array}{l}\text { International Law, The Netherlands } \\ \text { University of Comillas, Spain }\end{array} \\ \text { Rafkat J. Muhamedrahimov } \\ \text { David M. Brodzinsky } & \text { Saint Petersburg State University, Russian } \\ \text { Rutgers University, USA } & \text { Federation } \\ \text { Harold D. Grotevant } & \text { Julie Selwyn } \\ \text { University of Massachusetts Amherst, USA } & \text { University of Oxford, UK } \\ \text { Dana E. Johnson } & \text { John Simmonds } \\ \text { University of Minnesota, USA } & \text { CoramBAAF, UK } \\ \text { Femmie Juffer } & \text { Michael Tarren-Sweeney } \\ \text { Leiden University, The Netherlands } & \text { University of Canterbury, New Zealand }\end{array}$

(C) 2019, American Psychological Association. This paper is not the copy of record and may not exactly replicate the final, authoritative version of the article. Please do not copy or cite without authors' permission. The final article will be available, upon publication in 'Psychology, Public Policy, and Law' via its DOI: $10.1037 /$ law0000192

${ }^{1}$ Jesús Palacios. Department of Developmental and Educational Psychology, University of Seville. Calle Sevilla 10. 41960 Gines Seville, Spain. Email: jp@us.es ${ }^{2}$ The views expressed herein are those of the author alone and should not be attributed to or be understood to reflect the views of the Hague Conference on Private International Law. 


\begin{abstract}
Existing over many centuries, adoption has been challenged in recent years by evidence about practices that do not respond to the principles, ethics and laws under which it should be enacted. Written from a multidisciplinary and international perspective, this article outlines the place of adoption in the child protection system, as well as its core elements of permanence and stability. Recent demographic changes in adoption throughout the world are first examined. The negative consequences of children's exposure to early adversities and the post-adoption developmental trajectory of adopted people are also summarized. The focus of the argument is that adoption provides a legitimate model for the alternative care of children if undertaken within a rights and ethics framework that emphasizes children's best interests, as set out in international conventions and national laws. Implications for adoption policy and practice are presented.

Keywords: adoption, permanence, law, ethics, policy and practice
\end{abstract}




\section{Introduction}

Over many centuries, concern for the welfare of children whose birth parents or extended family cannot provide adequate care for them has been an important issue. The alternatives for those children are varied, including abandonment, placement within institutional care or with other families. Among the possible choices, placement in an adoptive family can offer the most personally, socially and legally stable caregiving option for many children.

While society has approved of the formal transfer of parental obligations and rights since the ancient Babylonians (1800 BCE), adoption has always faced challenging questions that reflect concerns about its intended purpose, processes and outcomes. Over time, the practice of adoption has been challenged by troubling unacceptable evidence about stolen babies, the oppression of birth parents and the abuse and/or neglect of children. Because of these controversies and disturbing accounts, there are strong views expressed that question the concept of adoption or demand very strict limits for its use, only under very extreme circumstances and when nothing else would work for a child. However, there are also equally compelling narratives where the survival of children and their positive development over time would not have happened if it were not for the contribution that adoption made in providing parenting and a family life that is lifelong (Ballard, Goodno, Cochran \& Milbrandt, 2015).

This article considers the implications of adoption and its place in the child protection system from a multidisciplinary international perspective. It is written by academics and practitioners in the fields of law and policy, medicine, psychology and social work. The first author convened this group, diverse in their connections to adoption, their nationalities, and their types of professional adoption expertise, but unified by their joint concern to establish a robust, ethical and evidence informed policy and practice framework. The conclusions drawn in this 
paper represent the consensus of this group, based on a children's rights perspective, as articulated in international conventions such as the United Nations Convention on the Rights of the Child (United Nations General Assembly, 1989). The well-being of the children involved (Cross \& Hershkowitz, 2017) is another critical component throughout the article.

One of the central arguments of the article is that for children who cannot remain or be reunified in their birth or extended family after the provision of appropriate focused services and interventions to their parents, early placement, stability and legal and relational permanence in a new family in the State of origin must always be prioritized. The child's well-being and lifelong safety, needs and welfare must be the primary focus, including their long-term recovery from maltreatment and relational uncertainty. Exposing the child to high-risk and unstable circumstances while waiting to see if something else would work is not a desirable alternative.

With the purpose of showing the wider sociological framework in which adoption takes place, this article starts with an analysis of recent worldwide changes in adoption demography within the broader framework of demographic changes in child protection. After this, the focus changes to present research evidence on the negative consequences of early maltreatment, as well as on the psychological cost of institutional experiences or family instability. Adoption is then presented as one of the main child protection alternatives, with lifelong permanence as a key objective. Once adopted, a new chapter starts in the life of the child and the outcomes of adoption are examined to identify its benefits, but also the long-term consequences of early adversity and the lifelong nature of adoption. The article continues embedding adoption within a rights and ethics framework as set out in international conventions and delivered through national laws. It is the duty of every country to ensure that such a framework enables all the people affected by adoption to feel both protected and respected. The final section of the article 
reflects on the policy and practice implications of the previous considerations. All these analyses refer to adoption as practiced across many countries, but are not necessarily applicable to all cultures and jurisdictions in the world.

\section{Adoption demography}

According to a United Nations (UN) report, the number of children adopted throughout the world annually was around 260,000 in the middle of the 2000s (United Nations Population Division, 2009). Most of these adoptions occurred in just a few countries: United States $(127,000)$; China (37,000); the Russian Federation (16,000); also in Brazil, Canada, France, Germany, Italy, Spain, Ukraine and the United Kingdom (4,000 to 6,000 each). All countries together, $85 \%$ of the adoptions were domestic, but the proportion of domestic versus intercountry adoptions varied a great deal between countries (e.g., 95\% intercountry adoptions in Belgium vs. 95\% domestic adoptions in the UK and 54\% in Canada). Since the UN report was published a decade ago, important changes have modified the demography of adoption worldwide.

Some of these changes have occurred outside the child protection domain, but might have had an impact on the number of children in need of alternative families or on the number of families who want to adopt as a way of becoming parents:

- The availability of contraception and the possibility of legalized abortion in many countries have significantly reduced unwanted pregnancies. In the years from 1990-94 to $2010-14$ there was a $30 \%$ reduction in developed countries and $16 \%$ in developing regions of the world (Bearak, Popinchalk, Alkema \& Sedgh, 2018).

- Around 530,000 babies are born every year through assisted reproductive technologies (ART), with seven million babies born this way since the first in vitro fertilization in 
1978 (European Society of Human Reproduction and Embryology, 2018). As ART becomes more effective and less costly, the motivation to adopt is likely to decrease.

- Although precise statistics are not available, it is estimated that by 2013 the number of children born through surrogacy arrangements was higher than the number of intercountry adoptions for the same year (Scherman, Misca, Rotabi \& Selman, 2016). Since then, surrogacy numbers have probably increased and intercountry adoptions have kept decreasing.

Traditionally, adoption focused on the placement of relinquished babies with infertile couples. In Western countries, the numbers of infants placed for adoption decreased in the 1970s resulting from the weakening of stigma regarding single motherhood and non-marital births, availability of welfare services that enabled mothers to care for their child and the demographic changes outlined above. The numbers of relinquished infants' adoptions in high-income countries have been extremely low for the past 40 years (Kahan, 2006).

In recent decades there has been a strong policy focus and values-based commitment to family preservation (such as the 2018 U.S. Family First Prevention Services Law) and reunification, with about half the children returned to their families after being in temporary outof-home placements (Petersen, Joseph \& Feit, 2013). In parallel, de-institutionalization of children's care has been taking place in an increased number of countries where residential care was the predominant care arrangement (Eurochild, 2017). In the Russian Federation, for instance, the number of children in public residential care decreased by $60 \%$ from around 180,000 in 2004 to near 73,000 in 2014 (TransMonEE, 2015). The combined impetus of these two changes has resulted in increased numbers of children in family foster care in the Russian Federation, from about 4,400 at the end of year 2000 to more than 134,000 at the end of 2014 
(TransMonEE, 2015). These figures dramatically illustrate the direct impact of deinstitutionalization of children on the increase of family-based care.

Regarding adoption, one of the most significant demographic changes is the sharp worldwide reduction in intercountry adoptions starting some years ago (Selman, 2009):

- For many receiving countries, an almost perfect inverted "U” shape can be drawn, with a steady increase during the 1990s, peaking in 2004 and a steady decrease starting in 2005. In countries with very different adoption traditions (Australia, Spain, Sweden and the United States), intercountry adoption numbers fell by around $80 \%$ to $90 \%$ between 2004 and 2017.

- A similar inverted “U” profile appears in the sending countries. In the Russian Federation, for instance, the number of children adopted abroad rose from around 1,500 in 1993 to around 9,400 in 2004, but then fell to near 1,000 in 2014 (a 90\% reduction) (Ministry of Education and Science of the Russian Federation, 2015; TransMonEE, 2015). This pattern is comparable to the $83 \%$ decrease in intercountry adoptions from China, from around 15,000 in 2005 (Selman, 2009) to less than 2,800 in 2016 (Ministry of Civil Affairs of the People’s Republic of China, 2018).

- Another factor contributing to the global decline in numbers of children has been the suspension of, or moratorium on intercountry adoptions in specific States of origin. These have often followed the identification of abuse, corruption, crime and children being trafficked for adoption (HCCH, 2015a).

The picture is more diverse in the case of domestic adoptions:

- In the USA, for instance, the number of domestic adoptions increased from around 55,000 in the years $1992-1996$ to around 76,000 in the years 2006-2007, and then fell to 
around 69,000 in 2014 (Jones \& Placek, 2017). The profile was similar in the countries of the European Union (EU): around 14,000 domestic adoptions in 2004, 20,000 in 2012 and 13,000 in 2014 (Jurviste, Sabbati, Shreeves \& Dimitrova-Stul, 2016).

- A steady decrease has taken place in both the Russian Federation (from around 14,000 domestic adoptions in 1993 to 5,900 in 2015, TransMonEE, 2015) and China (from around 30,000 in 2010 to 16,000 in 2016, Ministry of Civil Affairs of the People’s Republic of China, 2018).

- The pattern was different in Australia, with a significant decrease from the mid-1990s (around 630 domestic adoptions) to the mid-2000s (around 130), and then a more recent increase (near 250 in 2016) (Australian Institute of Health and Welfare, 2017).

In countries where the de-institutionalization of the care of children and the use of family foster care have a long tradition, a growing concern about multiple placements and instability has contributed to an emphasis on the importance of permanence:

- In the U.S. the Adoption and Safe Families Act of 1997 aimed at promoting permanency for children in care. This had a direct impact on the number of domestic adoptions, with a 40\% increase between 1996 and 2007 (Jones \& Placek, 2017).

- In England legislative changes introduced in 2002 increased the number of adoptions from the care system by 170\%, from around 2,000 in 1988 to near 5,400 in 2015 (Department of Education, 2018), although recent figures show a fall in these numbers.

- In countries where institutional care for young children still prevails (for example, Portugal and many countries in Latin America), new legal regulations banning residential care are expected to increase the use of family-based alternatives, including both foster care and adoption. 
Finally, as intercountry adoptions have decreased dramatically and domestic adoption numbers shrink in some countries, adopter profiles and types of adoption have expanded. Traditionally, married couples with identified social status were the only people likely to be approved to adopt. More recently, parenting capacity has become the primary assessment issue to be explored as society has become more open about sexual orientation, gender or marital status. This can be illustrated in England, where although most children were placed in 2017 with heterosexual couples (around 3,500), others were placed with single applicants (near 900) or same-sex couples (almost 600) (Department of Education, 2018).

Regarding types of adoption, two trends can be observed:

- The first one is illustrated by the U.S. figures for adoptions between October 2013 and September 2014, indicating that $81 \%$ of the adoptions nationwide involved children with special needs such as being older, with some kind of developmental delay or disability, or being part of a sibling group (US Children’s Bureau, 2016).

- The other is the development of open adoption (with some form of contact between the child and members of the birth family) in an increasing number of countries. As an example, the increase in domestic adoption numbers in Australia is accounted for by one state (New South Wales) where adoption is only available if open, thus facilitating the adoption of children in long-term foster care by their existing foster carers (del Pozo de Bolger, Dunstan, \& Kaltner, 2017).

\section{Consequences of neglect and maltreatment in the family and in institutional contexts}

In order to function within the normal range of physical, cognitive and social

development, young humans need to encounter circumstances that the evolution of our species defined as necessary to promote adaptation and developmental progress. Neglect and 
maltreatment create a high-risk environment for the developing fetus, infant and child and threaten the progress of a healthy developmental trajectory. This is particularly important given the accumulation of sensitive periods for growth and development during childhood. The experience of child maltreatment initiates a probabilistic path involving the chronic dysregulation of normal developmental progress, with a cascade of problems in physical, neurobiological, cognitive and socioemotional processes (Cicchetti, 2013).

In those countries where parental neglect and maltreatment in the family are followed by institutional or residential care, routinized schedules and lack of stable and sensitive care from committed caregivers often qualify as 'structural neglect' (Van IJzendoorn et al., 2011). The severity of children's delays and difficulties associated with this type of rearing environment is often significant, but may vary across different degrees of institutional deprivation (Woodhouse, Miah, \& Rutter, 2018).

Research has documented extensively the negative consequences of neglect, maltreatment and institutionalization on key aspects of children's growth and development:

- Together with a variety of health problems, linear growth, weight gain, and head circumference are all often diminished (Johnson \& Gunnar, 2011; Van IJzendoorn, Bakermans-Kranenburg, \& Juffer, 2007);

- Neurocognitive impairments have been reported following neglect and maltreatment, with negative consequences on executive functioning, intelligence, language, visualspatial skills, memory and academic achievement (Kavanaugh, Dupont-Frechette, Jerskey, \& Holler, 2017; Van IJzendoorn, Luijk, \& Juffer, 2008).

- Children reared in adverse, neglectful caregiving environments have demonstrated clear increased risk for developing attachment problems such as insecure disorganized 
attachments and reactive attachment disorder, with reduced social and emotional reciprocity, as well as disturbed emotion regulation (Lionetti, Pastore, \& Barone, 2015; Van IJzendoorn et al., 2011; Zeanah \& Gleason, 2015).

- Exposure to neglect, abuse and severely inadequate caregiving increases the lifetime risk for different psychopathological conditions such as depression, anxiety disorders, post-traumatic stress disorder, and internalizing and externalizing symptoms (Cicchetti \& Doyle, 2016).

As shown in Teicher and Samson’s (2016) review, the negative effects of child abuse and neglect can be enduring. Moreover, Nanni, Uher and Danese’s (2012) meta-analysis suggests slow remission of these difficulties and poor response to pharmacological and psychotherapeutic treatments.

Furthermore, when children with adverse early experiences in the family or in residential care are exposed to unstable foster placements, negative consequences can occur in the domains of growth, behavioral adjustment, mental health, educational achievement and social integration:

- Regarding growth, caregiving disruptions can adversely affect children's physical development, including the onset and progression of pubertal development (Johnson et al., 2018).

- For behavioral adjustment, Rubin, O’Reilly, Luan and Localio (2007) showed a significant increase in behavior problems due to instability alone, and this was unrelated to the baseline problems.

- The number of placement changes has been related to a greater use of outpatient mental health services (James, Landsverk, Slymen \& Leslie, 2004), and placement instability 
has been associated with a higher risk for offending trajectories after leaving care (Ryan, Hernandez and Herz, 2007).

\section{Child protection alternatives}

While most parents look after their children and are committed to their protection and well-being, a smaller number cannot or do not exercise their responsibilities in a way that keeps the child safe and promotes their development through to adulthood. The policies of different countries vary in the way these issues are addressed. However, the Universal Declaration of Human Rights of 1948 established a framework for what would become a legally binding set of

international human rights treaties and other measures, including the Convention on the Rights of the Child (United Nations General Assembly, 1989), as discussed later. This overarching framework has resulted in countries developing law, policies and practices to protect children from maltreatment and provide alternatives when these issues cannot be adequately addressed within the child's timeframe.

Considerable variation exists in the regulation of child protection systems, with a permanent tension between the State's duty and responsibility to preserve the family through the provision of services while having the power to remove children if they are at significant risk (Gilbert, Parton, \& Skivenes, 2011). Despite these differences, within the zones of the world covered in this paper, some basic principles shared by contemporary child protection systems are delineated below, along with some of the different emphases and alternatives. The way the child welfare or child protection system operates has been described as a filter and funnel system (Gibbons, Conroy \& Bell, 1995), a pathway with entry, exit and inter-connection points. The temporal sequence and the main alternatives are as follows: 
- Once child neglect and maltreatment are suspected, there is an initial professional screening. Cases screened out can be closed or referred elsewhere for support and services. Cases screened in are subject to further investigation to determine the degree of concern, risk and urgency, including a plan to address the issues identified.

- When there is significant harm or risk, critical decisions need to be made. The level of judicial involvement differs between jurisdictions. In some, all child protection decisions are authorised by the court, while in others judges are only involved when birth parents appeal child protection decisions and in cases involving changes in legal status and responsibilities. A mixed approach is also possible, with courts and child protection officials sharing decision making.

- For cases not involving immediate and significant harm, family preservation is the first option, and this typically involves the provision of interventions and services to improve family functioning and to avoid the need for out-of-home care.

- When it is identified that remaining with the birth parents is likely to result in significant harm or risk for the child, out-of-home care is needed. In some situations, the extended family may be able to provide alternative care. Where this is not possible, then, family-based alternatives such as foster care are given priority for most children (Dozier et al., 2014), with group care (residential or institutional) still used in some countries. While the preference for family alternatives started during the second half of the $20^{\text {th }}$ century in many countries, others are only now beginning to move in that direction, a change largely driven by research findings.

Only a small proportion of the children with suspected maltreatment are placed into outof-home care. For instance, U.S. statistics show that each year more than 3 million referrals are 
received, involving around 6 million individual children. However, the "filter and funnel” system only directs about $20 \%$ of these children into care (Petersen et al., 2013).

When a child is removed from his or her family, the first alternative is to explore and enable the possibility of family reunification. Children are typically placed in a temporary family foster home while providing interventions to improve their parents' capacity to ensure safety and provide loving and appropriate standards of care. Family reunification plans should always bear in mind the importance for the child in establishing a secure, stable and permanent family life. The primary issue is to ensure that children are not in impermanent placements for extended periods. Reported reunification rates for USA (Child Welfare Information Gateway, 2017) and Australia (Fernandez \& Lee, 2013) are around 50\%-60\%. Some of the reunifications are successful, but there are also cases of system re-entry due to abuse and neglect within the reunified family. In the UK, Farmer (2018) reports one third of returns to out-of-home care within six months and up to $65 \%$ in five-year follow-ups, with frequent repetitions of abuse and neglect while with the birth parents.

In many countries, the most common type of out-of-home placements is family foster care, with links with the birth parents preserved and with the parents continuing to be the child's parents in law. There are a wide range of policies and practices when the child is in need of a permanent placement because returning to their parents is not possible. Long-term or permanent foster care (with kin or strangers) is used when there is no prospect for reunification and adoption is not a possibility. In some countries, guardianship arrangements provide another option: the main parenting responsibilities are transferred to caregivers (typically, members of the extended family) outside of the care system, enabling the guardian to have day-to-day control 
over the child's life while the links with the birth parents are maintained. Long-term foster care and guardianship may last until the child's age of majority or in some cases beyond.

A child can be adopted when the parents give their consent or their parental rights are terminated by a court order without their agreement. When a child is subject to intervention by the child welfare system, adoption is only used for a small minority when compared to other forms of placement. Typically, these are the children where the birth family circumstances are high risk, with continuing identified actual or potential harm for the child. In 2010, 20\% of U.S. children in care were judged to be “adoptable” (Petersen et al., 2013), which is higher than in other countries (e.g., 10\% in Portugal, Instituto Segurança Social, 2018). Not all children with an adoption plan are placed for adoption — for example, when a suitable family cannot be found or, in some jurisdictions, when children of a legally defined age do not consent to being adopted. Substantial variation exists in the way different countries regulate adoption:

- In some countries (e.g., Sweden), adoption without parental consent is exceptional, while in others a significant proportion of adoptions occurs without consent (almost 50\% in England, for instance).

- In some jurisdictions, but not all, grandparents and other relatives may adopt.

- As discussed in the demography section, an increasing number of jurisdictions allow some form of contact between the adoptees and members of the birth family —open adoption — and allow adoptees access to their records.

- In some countries (e.g., Sweden and The Netherlands), adoption is almost always international, while in others domestic adoption is predominant (e.g., Portugal and the UK). Still in others (e.g., Australia, France, Italy, Spain, USA) domestic and intercountry adoption coexist with significant figures for both types. 
In summary, children are placed into out-of-home care when there is an unacceptable risk of serious and ongoing maltreatment. In most systems, the preference is to place children with families (kin or strangers) rather than in residential settings. The placement can be temporary, with support services being provided to the parents to ensure the child is safely and adequately cared for in a family environment. If family reunification is not viable within the child’s developmentally-critical timeframes, there is an urgent need to identify a legally approved permanent plan for the child. In these cases, long-term placements are sought for children through a full or partial transfer of parental responsibility to kin or strangers in foster care or guardianship placements, or through adoption. With the exception of adoption, these alternatives typically preserve legal links with the birth parents and lasts until the child comes of age.

For children at the most serious end of the child welfare "filters and funnel” system, adoption provides permanent new families for the cases where the birth parents' rights over the child are legally terminated, typically due to evidence of significant harm caused to or likely be caused to the child. Although for the reasons discussed in the demography section the incidence is nowadays much lower than in the past, adoption is also an alternative for orphaned or abandoned children who cannot be cared for by other family members, as well as for those whose birth parents choose not to parent after being fully counselled and supported.

\section{The importance of permanence and stability}

The plight of children in impermanent foster care and other forms of alternative arrangements has been known for some time and lead to the rise of the permanency planning movement (Fein \& Maluccio, 1992). In child welfare practice, the word 'permanence' is variously used to describe children’s legal care status, placement stability, and relationships with their caregivers (Brodzinsky \& Smith, 2019). 
- Legal permanence, preferably with the child's biological parents or, when not possible, with other caregivers such as adoptive parents or guardians, affirms the authority and responsibility of these individuals to make all relevant decisions and to take all appropriate actions in raising a child. An important implication of legal permanence is that the State also relinquishes its guardianship and custody. In other words, not only do the child and their caregivers acquire a relationship 'in law', but also the State withdraws from day-to-day involvement in their lives. In the case of adoption, the legal link remains for a lifetime.

- Residential permanence, often referred to as placement stability, emphasizes the importance of supporting continuity of caregiving in a designated home.

- Finally, relational permanence (or psychological permanence) refers to the extent to which dyadic and intra-familial relationships are characterized by: (1) close, primary attachments of a child or young person to their caregiver(s) and other family members; (2) reciprocal caregiver bonding to the child, manifesting as unqualified lifelong commitment; and (3) each person having a sense of belonging permanently to each other (i.e. seeing themselves as a family).

The primary policy objective should be to work not only toward legal and residential permanence, but also to prioritize children's well-being and their connections to significant attachment figures with a view to supporting a felt sense of continuity, nurturance, security, trust and safety in relationships with their caregivers (Brodzinsky \& Smith, 2019). While legal permanence facilitates relational permanence, its influence is more distal than are caregiver motivation and commitment. The quality of caregiving is regulated by the caregivers' commitment (Dozier, Grasso, Lindheim, \& Lewis, 2007), and children need caregivers who feel 
entitled to assume full responsibility as parents, who are motivated to form an enduring parental bond and who are ready to commit to them permanently and without qualification for the remainder of their lives. For those children for whom it is a possibility, adoption offers life-long stability that promotes a thorough and deeply ingrained feeling of filiation and permanence (e.g., Rosnati, 2005).

The journey to relational permanence requires caregivers to develop an understanding and acceptance of the child's attachment- and trauma-related behaviors, and to recognize them as developmental consequences of early maltreatment (Purvis et al., 2015). It also requires that the child gradually starts to attach and belong to the new family. The permanence and stability afforded by adoption facilitate caregivers' commitment and bonding, as well as the extent to which children are emotionally nurtured (Schofield \& Beek, 2018). The most critical therapeutic mechanism for recovery from previous difficulties and achieving relational permanency is that a child is loved unconditionally within the context of age appropriate structure and rules, as well as realistic parental expectations regarding the child and themselves (Ackerman \& Dozier, 2005). To support relational permanence and children's long-term emotional well-being, especially for those youngsters with histories of maltreatment and trauma, it is critical that child welfare policy and practices promote stability in these children's lives and ensure ready availability of specialized therapeutic support services by well-trained adoption competent clinicians (Brodzinsky, 2013), as discussed later in this article.

It is also important to emphasize that children and young people can retain varying degrees of relational permanence to people they have lived with previously, including their parents, extended family, siblings, former foster parents, and foster siblings (Cushing, Samuels, \& Kerman, 2014). Child welfare policy and practices have not sufficiently recognised the 
importance of maintaining established, 'psychologically permanent' relationships when children are placed into care, or move from one care placement to the next, or exit care to guardianship or adoption (Stott \& Gustavsson, 2010). This is especially critical for children who enter care at older ages with very established family relationships, as well as for children who are moved from foster parents to adoption by another family.

As discussed in detail below, placement instability is a common experience encountered by children in care, being less frequent for children in permanent placements (Rolock \& White, 2016). Placement disruptions are experienced as acutely stressful events and incur further deterioration in children's mental health (Newton, Litrownik, \& Landsverk, 2000). Placement moves are experienced as a series of losses and rejections that generate negative emotions and beliefs about themselves and their caregivers, degrading their trust in others and their capacity to form close relationships, the effects of which persist into adulthood (Hébert, Lanctôt, \& Turcotte, 2016; Milan \& Pinderhughes, 2000).

A critical consequence of both planned placement changes and unplanned disruptions is that each change 'resets the clock' on a child's pathway to relational permanence. Close, enduring familial relationships grow over time in dynamic and complex ways, and for children this process is strongly influenced by their previous relationships and any significant losses (e.g., Milan \& Pinderhuhges, 2000).

Child welfare policy and practice must do everything possible to ensure that legal, residential and relational permanence remains a priority for children in care and that all efforts to achieve these goals are implemented in a timely and professional manner. Amongst the alternatives in out-of-home placements, adoption facilitates a life-long experience of belonging, a sense of stability and permanence that promotes recovery from past difficulties and the type of 
enduring bonding that nurtures psychological and relational well-being. In other words, adoption facilitates all three types of permanence.

\section{Postadoption outcomes}

Following placement, adopted children show substantial catch-up from their delays in all domains of development and outperform the children who remained in vulnerable families or in institutional care (Van IJzendoorn \& Juffer, 2006), although they also lag behind their nonadopted peers in some domains. The term “differential plasticity” (Palacios, Román, Moreno, León, \& Peñarrubia, 2014, p. 170) refers to the fact that some domains seem more likely to show improvement, while others are less amenable or take longer to change.

The high-quality rearing environment usually found in adoptive families may reduce, though not completely eliminate, the risk of negative health outcomes:

- Rapid recovery in height and weight from preadoption deficits is observed once children are adopted, with a slower and more incomplete profile for head circumference (Johnson \& Gunnar, 2011; Van IJzendoorn, Bakermans-Kranenburg \& Juffer, 2007).

- Several years after placement, parental perception of their adopted child's health (Hellerstedt et al., 2008) and the self-perceived health of adopted adolescents (BergKelly \& Eriksson, 1997) are quite positive. Likewise, a Dutch cohort study found that adoptees generally do not use more medication than their nonadopted peers for depression, ADHD or growth inhibition/stimulation (Van Ginkel, Juffer, BakermansKranenburg, \& Van IJzendoorn, 2016).

- A higher risk of early puberty, particularly in girls, may be related to either adverse experiences prior to adoption, or to endocrine changes such as rapid catch-up growth (Johnson \& Gunnar, 2011). 
Research shows positive changes in cognitive development and related domains, although the levels of performance may vary between different domains:

- A meta-analysis found no IQ differences between adoptees and non-adopted peers, although adopted children showed more learning problems than their non-adopted peers (Van IJzendoorn, Juffer, \& Klein Poelhuis, 2005).

- A Swedish study on cognitive competence and educational achievement (Vinnerljung \& Hjern, 2011) found that, although domestic adoptees did less well than their nonadopted counterparts, the adoptees outperformed children in long-term foster care.

- Regarding executive functioning (EF), in adoptions after early institutional deprivation, some aspects of EF present average levels (e.g., rule acquisition and planning, Pollak et al., 2010), whereas in others the negative impact is still evident years afterwards (e.g., inattention and over-activity, Sonuga-Barke et al., 2017).

Finally, in adopted children's socio-emotional and mental health domains, findings report both the significant benefits of adoption and the persistence of some problems:

- Over time, adopted children's attachment security increases towards a more normative level of security, although the proportion of insecure disorganized attachment is higher in adopted than in nonadopted children (Van den Dries et al., 2009).

- Severe early emotional deprivation may remain associated with disinhibited social engagement behavior (Sonuga-Barke et al., 2017) and with negative thoughts and feelings about close relationships (Raby \& Dozier, 2018).

- Most adopted youth are well adjusted, but adoptees as a group have more mental health problems and are over-represented in mental health services compared with non- 
adopted peers (Askeland et al., 2017; Barroso, Barbosa-Ducharne, Coelho, Costa, \& Silva, 2017).

Some variables are related to the degree of cognitive and socio-emotional recovery after adoption:

- Adoptees with substantial preadoption adversity have more behavior problems than those without such experiences (e.g., Juffer \& Van IJzendoorn, 2005), and intercountry adoptees from different countries of origin and backgrounds may show divergent and heterogeneous outcomes (for example with respect to rates of criminal offending, Van Ginkel, Juffer, Bakermans-Kranenburg, \& Van IJzendoorn, 2018).

- Adoption at older ages is associated with more problems in cognition and with EF difficulties (Helder, Mulder, \& Gunnoe, 2014).

- Higher adoptive mother education and a parental style encouraging greater age-expected behavior contributes to IQ improvements of late-adopted children (Helder et al., 2014).

- Secure attachment increases with sensitive adoptive parenting (Barone, Lionetti, \& Green, 2017).

Regarding self and identity development, the main areas covered in adoption research include self-esteem, ethnic identity, adoptive identity, and searching for origins.

- For self-esteem, no significant differences with non-adopted subjects have been reported for domestic, transracial, or international adoptees (Juffer \& Van IJzendoorn, 2007).

- Regarding ethnic and racial identity, the benefits of a stronger ethnic identity have been associated with greater psychological well-being (Basow, Lilley, Bookwala, \& McGillicuddy-DeLisi, 2008). Children raised in “color-blind” adoptive homes, or 
homes where parents who may acknowledge race differences fail to discuss them, can be unprepared for the discrimination they may encounter when entering the broader world as teenagers and adults (e.g., Ferrari, Rosnati, Canzi, Ballerini, \& Ranieri, 2017; Pinderhughes, Matthews \& Zhang, 2016).

- Regarding adoptive identity, adolescents adopted domestically as infants by same-race parents varied considerably in their paths to adoptive identity: around 50\% paid little or no attention to adoption issues, 30\% showed high levels of exploration and positive feelings about adoption, and around 20\% showed considerable exploration and high negative affect about adoption (Dunbar \& Grotevant, 2004). In their mid-20s, those in the last group showed more internalizing problems (Grotevant, Lo, Fiorenzo, \& Dunbar, 2017). Positive appraisal of adoption was related to higher levels of well-being in international adoptees (Rushton, Grant, Feast \& Simmonds., 2013; Ter Meulen, Smeets, \& Juffer, in press).

- Related to self and identity is adoptees’ natural curiosity about their origins. Adolescent adoptees are primarily interested in having an adult understanding of why they were placed for adoption (Wrobel \& Dillon, 2009). Emerging adult adoptees (age 21-30 years) are primarily interested in knowing about their medical and family health histories (Wrobel \& Grotevant, 2019). Searching for birth relatives tends to occur more in young adulthood than in adolescence (Triseliotis, Feast, \& Kyle, 2005). In a sample of adult international adoptees, 32\% had searched for birth family (Tieman, Van der Ende, \& Verhulst, 2008). Whether curiosity becomes demonstrated through information seeking depends on the presence of barriers (e.g., not wanting to hurt parents), as well as facilitators (e.g., feeling ready, having resources) (Wrobel, Grotevant, Samek \& Von 
Korff, 2013). The use of internet and affordable DNA analytics that can identify biologically related individuals is making search for origins more common.

More research is currently being conducted with adult adoptees. Results have demonstrated overall good adjustment, but also that the duration, intensity, and nature of the deprivation prior to adoption affect post-adoption outcomes:

- Despite a poor start, mid-life outcomes for women adopted from Hong Kong to the UK around the age of 2 years were comparable with non-adoptees in educational attainment, mental and physical health (Feast, Grant, Rushton, Simmonds, \& Sampeys, 2013).

- A Swedish study comparing siblings with experience of out-of-home care during at least five years, some of whom were adopted before their teen years while others were never adopted, showed that adopted siblings tended to have considerably better outcomes in adult age in educational achievement, income, criminality, disability and suicidality. (Hjern, Vinnerljung, \& Brännström, in press).

- Children adopted internationally to the Netherlands in their early years and followed into adulthood were on par with the general population in terms of socioeconomic success (Schoenmaker et al., 2015; Tieman, Van der Ende, \& Verhulst, 2005).

- While adult adoptees on average have more psychological difficulties than nonadopted persons (e.g., higher levels of depression and anxiety), there is considerable heterogeneity in their psychological well-being. This variability is accounted for by a range of mediating factors, such as age at placement, gender, and quality of relationships within the adoptive family (Melero \& Sánchez-Sandoval, 2017). Adoptees may also encounter post-adoption experiences with long-term consequences: 
- In open adoption arrangements, satisfaction with contact, rather than existence or type of contact, predicted less externalizing behavior during emerging adulthood (Grotevant, Rueter, Von Korff, \& Gonzalez, 2011).

- During adolescence or in adulthood, children adopted transracially into white families may have experiences with a potential negative impact on their wellbeing: racial discrimination, microaggressions, exposure to negative media portrayals or difficulties in the process of racial/ethnic identity development (e.g., Baden, 2016; Ferrari et al., 2017).

Due in part to the reduction in stigma about adoption and the increased visibility of adoption research in recent times, a growing number of adult adoptees are taking up professional roles in the field and sharing their personal histories. It will be increasingly important for the professionals in the field to acknowledge and learn from these lived experiences (McGinnis, Baden, Kim, \& Kim, 2019).

The studies summarized in this section highlight many factors that mediate and moderate adoption outcomes. The literature is also clear that adoptive family structure (e.g., single vs. two parent; gay/lesbian vs. heterosexual; racial background) is less important for outcomes than are family processes, such as sensitivity to the child's needs, open parent-child communication, supportive co-parenting, and low stress (e.g., Farr \& Patterson, 2013; Johnson et al., 2010).

Finally, the study of adoption outcomes cannot ignore the fact that not all the adoptive placements achieve the intended aim of life-long legal and psychological connection to the adoptive family. Studies about the incidence of adoption breakdown have reported rates that vary between $1 \%$ and $27 \%$ depending on the sample characteristics (e.g. infants or special needs), the time span considered, and the quality of the data (Palacios, Rolock, Selwyn \& Barbosa- 
Ducharne, 2019). Incidence rates tend to be lower in Europe (below 5\%) than in the U.S. (9.5\% for pre-adoption placements and 2.2\% for finalized placements, Smith, 2014), and lower for intercountry than for domestic adoptions (Palacios et al., 2019). The incidence rates report known adoption breakdown cases, but there are also others unknown to the authorities. In addition, there are many adoptive families that stay intact, but struggle with relational difficulties (estimated between a quarter and a third of adoptive placements by Smith, 2014).

Adoption breakdown is not usually the consequence of one specific cause, but rather of an accumulation of risk factors (Palacios et al., 2019). Typically, these pertain to characteristics of the child (more pre-adoption adversity, older age at placement, more troubled behavior), the adoptive parents (e.g., motivations to adopt more centered on the adults' than on the child's needs, inadequate expectations, limited parental skills) and support and service (e.g., insufficient or ineffective pre- and post-adoption support). The harmful effects and consequences of placement instability were described earlier in this article.

Taken together, these diverse outcomes demonstrate that adoption needs to be thought of as a life-long experience, both in terms of benefits and potential difficulties. Three findings stand out: adoption introduces a major positive change in adopted persons’ life trajectory. However, there is convincing evidence that pre-adoption adversity (abuse and neglect, malnutrition, multiple separations) may have substantial short- and long-term negative consequences for adopted children’s development. Furthermore, the adopted population is quite heterogeneous, and mediating and moderating effects play important roles in predicting adult outcomes.

\section{Legal rules and ethical standards regarding adoption}

The legitimacy of adoption has been rightly challenged as issues have been identified that involve the sale of children, abduction, trafficking and other abuses occurring in different times 
and places. Adoption policy, law and practice must respect international treaties, domestic legislation and other legal and ethical standards and rules. Adoption should only become a child's plan if it serves the child's immediate and long-term interests and is lawfully decided on a case-by-case basis. This section presents a summary of the fundamental legal and ethical standards that must be considered in relation to the child, the birth family and the actors participating in the adoption procedures.

Legislation and ethical standards on adoption are based on the main binding international treaties in this area. These include the UN Convention on the Rights of the Child (CRC) (United Nations General Assembly, 1989), which is the universal expression of consensus on the rights of the child. Also, the 1993 Hague Convention on Protection of Children and Co-operation in respect of Intercountry Adoption (HC) $(\mathrm{HCCH}, 1993)$, which establishes minimum safeguards for the protection of children in intercountry adoption. At the European level, the European Convention on the Adoption of Children (EC) (Council of Europe, 1967) and the European Convention on Human Rights (ECHR) (Council of Europe, 1950) establish safeguards for children in care and adoption. There are also "soft law” instruments such as 2010 UN Guidelines for the Alternative Care of Children (United Nations General Assembly, 2010), which provides guarantees to ensure the principle of subsidiarity as detailed below. States parties to any of these Conventions should develop domestic rules and procedures to ensure that these international obligations and safeguards are properly regulated and implemented in their territory. The child

The CRC (Art. 21) states that the best interests of the child is THE paramount consideration in adoption, above other legitimate interests of the birth or adoptive families (Cantwell, 2014). In line with that, the following principles can be underlined (HCCH, 2008): 
- Family is the natural environment and the best place for the growth, well-being and protection of children, and therefore it should be protected (Arts 9, 10 CRC, Preamble HC, Art. 8 ECHR). Children should not be separated from their parents other than where competent authorities determined that such separation is in their best interest (Art. 9 CRC). In their national legal provisions, States should support efforts to keep children in, or return them to, the care of their family. The role of the extended family and community is key.

- If it is not possible for the child to be cared for by her or his family of origin, the relevant authorities as defined in each State regulation should try to find another appropriate and stable family solution, if possible within the same country. In States governed by the Sharia law, kafala may be an option. These solutions are subsidiary to the child being raised by his or her family of birth (Art. 21 CRC; Preamble HC).

- While an appropriate and permanent solution is being sought, or in cases where such a solution is not possible or not in the best interests of the child, the most suitable forms of alternative family care should be identified and provided, under conditions that promote the child’s full and harmonious development (United Nations General Assembly, 2010). These alternative family environments should always be 'goodenough care arrangements' that serve the basic attachment needs of the child (Van IJzendoorn, Bakermans-Kranenburg, Duschinsky, \& Skinner, in press). Placement in suitable institutions should always be a temporary measure and not used for young children (Dozier et al., 2014). All these decisions should be made within a childcentered time-frame. 
- Intercountry adoption shall take place only if the competent authorities of the country of origin have determined, after possibilities for domestic placement have been given due consideration, that an intercountry adoption is in the child's best interests (principle of subsidiarity, Art. 4 HC; Art. 21 CRC);

- Adoption must not be considered when there are allegations of corruption and trafficking, and in cases of armed conflict or natural disasters (HCCH, 2008).

- Parents from a specific ethnic, cultural, religious or social heritage, as well as those living in poverty, should never be, by definition, considered incapable of taking care of their children (Arts 2 and 9 CRC; Arts 9 and 15 UN Guidelines). Children should only be declared adoptable if they are orphans, abandoned or exposed to serious risk through the lack of adequate exercise of the parental responsibilities by birth parents.

Regrettably, this has not always been the case and children who could have been cared for in their birth families and were not in need of adoption were adopted, while other children in real need of an adoptive family languished in institutions.

- Only children who have been legally declared adoptable should be adopted (Arts 9 and 21 CRC; Arts 4 and 16 HC). The declaration of adoptability — a key stage of any adoption — should always be done by a competent authority after ensuring all the needed checks and balances (HCCH, 2008).

- A child should be declared adoptable before any contact takes place between the birth parents, or any person who has the care of the child, and the prospective adoptive parents (Art. 29 HC). Exceptions to this rule are intra-family and step-parent adoptions, as well as adoption of foster children by their foster parents where this is permitted. In all cases, prospective adopters should be counselled, need to be declared eligible and 
suitable to adopt and respect all other legal standards before the adoption takes place.

- Adoptees have the right to know about their origins and have access to information, in so far as permitted by the law of a State. To that end, the information concerning the child (e.g., family and medical history) should be collected and preserved by competent authorities. Having access to that information, and doing so with the adequate support to understand and explore it, is key to the development of a child's identity (Arts 7 and 8 CRC; Arts 9, 16, 30, and 31 HC; Art. 22 EC). As with the previous and subsequent provisions, this one should be reflected in each country legal regulation.

- The child has the right to be heard in the administrative and judicial adoption proceedings and should consent to the adoption, when required and in accordance with his/her age and maturity. Consent should only be lawfully given after having been properly counseled and informed (Art. 21 CRC; Art. 4 HC; Art. 17 EC, HCCH 2014).

The families

All those who need to consent to the adoption (e.g. persons, institutions, authorities) should do so after being properly informed and counseled about the effects of adoption (Art. 21 CRC; Art. 4 HC; Art. 5 EC). This is especially important in the case of birth mothers. When they are properly informed, counselled and supported, there is a higher likelihood that they will decide to keep and raise their children (Consejo Nacional de Adopciones de Guatemala, 2008). When this happens, and the safety and well-being of the children involved are not at risk, they should receive long-term support to fully enable them to care for the child (Arts. 5 and 18 CRC).

- Any consent to adoption should be given freely and must not be induced by any type of payment or compensation. It should be given in the required legal form expressed or evidenced in writing and should not have been withdrawn. Birth parents should only 
give consent after the birth of the child, not immediately or in the postpartum period, but after the period of time established in the law (Art. 4 HC).

- Public authorities may have to consent to the adoption of orphans, abandoned children and those whose parents are unknown. In addition, in many States, in cases of lack of adequate exercise of the parental responsibilities, a competent authority —usually, a court - can deprive the biological parents of their parental rights, even if they do not consent (Doughty, Meakings \& Shelton, 2019; Fenton-Glynn, 2015). Some countries only allow adoptions without consent under very exceptional circumstances. The implications of non-consensual adoption will be discussed in the following section.

- In the case of prospective adoptive parents, they need to be declared eligible (legal criteria), but also suitable (health and psychosocial criteria) by a competent authority as regulated in each State legislation. They should also receive proper preparation and support services before, during and after the child's placement with them (Art. 5 HC; Art. 9 EC).

- Child-parent(s) matching should always be done by a professional team and be followed by a probationary period supervised by professionals (Art. $20 \mathrm{HC}$; HCCH, 2008). If this period is successful, and after ensuring that all guarantees have been respected, the relevant competent authority — typically, a court — may issue the adoption decision.

- Post-adoption is also key: counselling and support, as well as other services, should be affordable and accessible to adoptees and their families when needed (Art. 9 HC). This support may help identifying and addressing issues in a timely manner.

\section{Institutions and bodies}

All authorities and bodies taking part in the adoption process should be properly, 
regularly and closely authorized, supervised and monitored by the relevant authorities (Art. 21 CRC; Arts 6, 10 to 12, 22 and 32 HC). National or State regulations must ensure that they also have the necessary powers and resources to carry their tasks.

Only professionals who are trained and competent in understanding adoption should be responsible for delivering adoption services. They may charge reasonable and lawful fees, but improper gains should be clearly prohibited in adoption (Art. 32 HC; HCCH, 2015b).

States should ensure a clear division of responsibilities between authorities and bodies, as well as proper communication and co-operation at domestic and international levels (Art. 21 CRC; Arts. 1, 7, 9 HC; HCCH, 2012). This is key to ensure that the often scarce resources available for child protection and adoption are well used and the duplication of tasks is avoided.

In conclusion, if an adoption is being considered, there is a wide range of ethical and legal standards to ensure that the best interests of the child is THE primary and paramount consideration. While legal and policy developments have been significant, States should not be complacent and should continue monitoring closely the full implementation of the ethical and legal framework to prevent any abuse and illicit practice. In addition, when abuses occur or are discovered, States should address them and provide remedies for the victims. Adopted persons should be properly listened to, respected, accompanied and supported. Adoption is rightly criticized when it is not child-centered and in cases where abuse of any kind was involved. But if it respects all international and national rules and guarantees, adoption may be one of the best alternatives for children who need a family for life.

\section{Policy and practice implications}

The research set out in the previous sections has significant implications for legislators, policy makers and professionals, as well as for the delivery of best child-centered practice. 
- Family-based care: The evidence clearly shows that family-based care is overwhelmingly preferable to institutional care. Policy and legislation in most countries now support this, but there are still many countries in the world that need to prioritize family care over institutional care in their legal and policy frameworks and day-to-day practice. It is important that they comply with the UN guidelines on children in alternative care recommending stable family solutions that meet the children's basic need for safe and continuous attachment to their caregivers (United Nations General Assembly, 2010, Section II, B.12). This principle indicates not only the pre-eminence of family over institutional care, but also the need to promote permanent over short-term planning for the child. As discussed in the demography section, the number of adoptions increases when laws reflect these principles and policy embeds them into practice.

- Foster care: In many countries, foster care is the primary model of family based care and for many children this is the right choice, particularly when family reunification is the plan. However, children placed in foster care may be subject to considerable uncertainty in the permanence of those placements and then there will be the significant question of what happens in their legal progression to adulthood -frequently an accelerated and compressed transition to independence (Stein, 2006). Young men and women who age out of the foster care system without stable, committed, nurturing relationships can face a range of challenging issues from education and employment to mental health and social integration (Rebbe, Nurius, Ahrens, \& Courtney, 2017).

For all children, there is a core question about their need for permanence through a family life where an enduring sense of stability, security, belonging and commitment are the key factors - in other words, a family for life. Children who are unable to return 
to their birth families and have no suitable relatives as long-term carers have both a right to and a need for a family life that extends beyond childhood into adulthood. The question for every child in a foster care placement is whether this is what will happen.

- Adoption and permanence: Adoption is clearly one of the answers to this issue. But in those state care systems where adoption is a lawful option, the proportion of children who have adoption as their permanence plan is very small compared to the overall care population. For that group of very vulnerable children, their permanence plan is determined by their individual best interests when their age, needs, welfare and development for the rest of their lives is the core question.

The adoption plan is made to ensure that their legal, residential and relational permanence -as discussed earlier- are the priority issues. For all those children whose circumstances make it a viable alternative, adoption should be considered as a placement option, compliant with local laws and ethical standards as set out earlier, including, where appropriate, the child’s consent.

- The challenge of non-consensual adoption: Some children might need an alternative permanence plan because of the significant risk to their safety and development if they were to continue to live in their birth families. However, their parents may not agree with the adoption plan. Based on the available evidence, with the child's well-being as the central argument (Cross \& Hershkowitz, 2017), professionals must make a childcentered plan that minimizes the risk to the child and maximizes the opportunity in addressing the core issue of the child's need for protection and permanence.

The European Court of Human Rights states that "where the maintenance of family ties would harm the child's health and development, a parent is not entitled to 
insist that such ties be maintained” (Fenton-Glynn, 2015, p. 31). This argument aligns with the requirement by CRC article 3 that in cases of disagreement the State must "find the solution that is in the best interest of the child". The balance of the evidence must be shown to fall on the side of a plan that prioritizes the child's safety and well-being in the immediate and longer term, and that adoption is the plan that will best enable this. It is also essential that any evidence in relation to the parents is tested against the evidence as to whether they have the capacity to positively change within the child's developmental timeframe. The adoption plan must be tested in the courts to ensure that both the birth parents' and the child’s rights are protected.

- Minimizing delay: Research shows that the effects of maltreatment and trauma can be enduring and that a longer delay before adoption will increase the negative effects on child development (Johnson, 2000). Minimizing the exposure to these adverse circumstances is key to reduce damage and to create significant opportunities for recovery and development into the future. Focused and sustained efforts are needed to identify and tackle delays in systems and procedures. The development of practices that facilitate early placement models such as 'concurrent planning' and 'fostering to adopt' should be explored and implemented (Dibben \& Howorth, 2017).

- Adoptive parenting: The quality of adoptive parenting has come to be seen as unrelated to simple and restricted categories such as age, gender, sexuality or marital status. A diverse group of adults (e.g. single, gay/lesbian, married or unmarried) can successfully adopt and parent children with a wide range of needs when they are well motivated, fully prepared, appropriately assessed and supported. The diversity of adoptable children's needs is better served by a parallel diversity in prospective 
adopters’ profiles. Parental capacities, motivation, resilience and commitment must take priority over any type of socio-demographic definitions (Golombok, 2015).

The uncertainties regarding the long-term recovery from the negative impact of early adversities, as well as the life-long nature of adoptive identity, require adopters who, with adequate support, are able to respond to the evolving needs of their adopted children. This capacity is key when recruiting, preparing, assessing and supporting adopters. Their tasks are complex and multiple, their expectations need to be reformulated along the way, the challenges from the adoptee can be quite difficult and yet, with due support if needed, they should be able to respond in a positive and appropriate way to their children’s characteristics and needs.

- Sharing information: Adoption is a powerful intervention but, on its own, cannot be expected to be the answer to every challenge faced by the child or the adopters. To improve the likelihood of successful adoptions, adoptive parents need to be given full information on the child, be educated on the impact and implications of maltreatment, as well as on the adoption life cycle. Similarly, children need to be prepared, and information and photos/mementos of their life stories preserved for them and actively woven into their life story narrative. Thorough assessments of children’s needs and potential adopters' competences lead to more secure matches and a more accurate prediction of what might be expected in relation to children's developmental progress and potential (Farmer \& Dance, 2016).

- Contact: Evidence suggests that, when in a child's best interests, contact with birth relatives and with previous caregivers can be helpful; agencies need to develop plans to facilitate and support this contact. The concept of adoption has moved from being 
thought of as 'closed and secret' to one that recognizes the need for greater openness and transparency and acknowledges the child's past history. Transparency also includes the child's right to access their own case records when reaching their majority.

- Support services: The availability of well-resourced and accessible pre- and postadoption services is critical for placement stability and the emotional well-being of all family members. This is especially so given the increasing challenges faced by families adopting older and special needs children (Barone, Ozturk, \& Lionetti, 2019; Smith, 2014), as well as some long-lasting consequences of early adversity, as reviewed before. Adoption is a lifelong experience and support may be needed over the life span. Practitioners should ensure that adopters are aware of available support services and reframe support seeking as a family strength rather than shameful or a parenting failure. Birth parent support should also be provided to enable them to manage contact, help resolve issues of loss, and accept the adopters as the parents of their child.

Research suggests that those seeking post-adoption services often find that mental health professionals do not understand their unique histories, as well as the challenges they face on a day-to-day basis. As a result, the guidance and treatment provided is often ineffective, and, in fact, sometimes does more harm than good. There is a growing consensus that to meet the needs of those touched by adoption mental health professionals need better training in adoption-related issues (Brodzinsky, 2013). In response to this need, a number of post-graduate training programs, as well as online training courses, have been developed, both in the U.S. and parts of Europe (e.g., Atkinson \& Riley, 2017). Research into evidence-based adoption interventions is now 
underway (Barone et al., 2019; Juffer \& Bakermans-Kranenburg, 2018; Quality Improvement Center for Adoption and Guardianship Support and Preservation, 2019). Adoption continues to be an evolving area of child placement practice. Over time, the models for adoption have been very different both in the problems they were meant to solve and the processes which enabled adoption to happen. Current models are also diverse depending on the country in which they operate and the problems they are intended to solve. The dilemmas, uncertainties and conflicts identified in this article will continue, in part because of the fundamentally embedded belief in every society that children should be raised by their parents and in their birth family. When this is not possible —and there are many reasons why this could be the case-- finding a solution is not straightforward and will inevitably stir up powerful feelings. The one thing that is agreed is that the child's safety, needs, welfare and development are the core issues to consider not only in the short term, but also for the rest of their lives. Embedded within this is a fundamental recognition that family life is the basic structure that enables this, and if that cannot be with the family of origin, an alternative permanent family solution must be found. In child protection, there could not be a more fundamental question requiring a robust, meaningful and informed solution. Vulnerable children are at the center of all of these issues and it is for them that we need an answer. 


\section{References}

Ackerman, J. \& Dozier, M. (2005). The influence of foster parent investment on children's representations of self and attachment figures. Applied Developmental Psychology, 26, 507-520. doi:10.1016/j.appdev.2005.06.003

Askeland, K.G., Hysing, M., La Greca, A.M. Aarø, L.E., Tell, G.S., \& Sivertsen, B. (2017). Mental health in internationally adopted adolescents: a meta-analysis. Journal of the American Academy for Child and Adolescent Psychiatry, 56, 203-213. doi:10.1016/j.jaac.2016.12.009

Atkinson, A.J., \& Riley, D. (2017). Training for adoption competency: Building a community of adoption-competent clinicians. Families in Society: The Journal of Contemporary Social Services, 98, 235-242. doi:10.1606/1044-3894.2017.98.23

Australian Institute of Health and Welfare (2017). Australia's welfare 2017. Australia's welfare series no. 13. AUS 214. Canberra: AIHW.

Baden, A. L. (2016). “Do you know your real parents?” and other adoption microaggressions. Adoption Quarterly, 19, 1-25. doi:10.1080/10926755.2015.1026012

Ballard, R., Goodno, N. H., Cochran, R. F., \& Milbrandt, J. A. (2015). The intercountry adoption debate: Dialogues across disciplines. Newcastle upon Tyne: Cambridge Scholars Publishing.

Barone, L., Lionetti, F., \& Green, J. (2017). A matter of attachment? How adoptive parents foster post-institutionalized children's social and emotional adjustment. Attachment and Human Development, 19, 323-339, doi:10.1080/14616734.2017.1306714

Barone, L., Ozturk, Y., \& Lionetti, F. (2019). The key role of positive parenting and children’s temperament in post-institutionalized children’s socio-emotional adjustment after 
adoption placement. A RCT study. Social Development, 28, 136-

151. doi:10.1111/sode.12329

Barroso, R., Barbosa-Ducharne, M., Coelho, V., Costa, I., \& Silva, A. (2017). Psychological adjustment in intercountry and domestic adopted adolescents: A systematic review. Child and Adolescent Social Work Journal, 34, 399-418. doi:10.1007/s10560-016-0485-X

Basow, S. A., Lilley, E., Bookwala, J., \& McGillicuddy-DeLisi (2008). Identity development and psychological well-being in Korean-born adoptees in the U.S. American Journal of Orthopsychiatry, 78, 473-480. doi:10.1037/a0014450

Bearak, J., Popinchalk, A., Alkema, L., \& Sedgh, G. (2018). Global, regional, and subregional trends in unintended pregnancy and its outcomes from 1990 to 2014: Estimates from a Bayesian hierarchical model. The Lancet Global Health, 6, e380-e389. doi:10.1016/S2214-109X(18)30029-9

Berg-Kelly, K. \& Eriksson, J. (1997). Adaptation of adopted foreign children at mid-adolescence as indicated by aspects of health and risk taking -a population study. European Child and Adolescent Psychiatry, 6, 199-206.

Brodzinsky, D. (2013). A need to know: Enhancing adoption competence among mental health professionals. Retrieved from https://www.adoptioninstitute.org/publications/a-need-toknow-enhancing-adoption-competence-among-mental-health-professionals/

Brodzinsky, D. \& Smith, S.L. (2019). Commentary: Understanding research, policy, and practice issues in adoption instability. Research on Social Work Practice, 29, 185-194. doi:

\section{$10.1177 / 1049731518782647$}

Cantwell, N. (2014). The best interest of the child in intercountry adoption. Florence: UNICEF. Instituto Segurança Social (2018). Caracterização anual da situação de acolhimento das crianças e jovens (Annual Report on children and youth care). Lisboa: ISSIP. 
Child Welfare Information Gateway (2017). Supporting successful reunifications. Washington, DC: U.S. Department of Health and Human Services, Children’s Bureau.

Cicchetti, D. (2013). Resilient functioning in maltreated children - Past, present and future perspectives. Journal of Child Psychology and Psychiatry, 54, 402422. doi:10.1111/j.1469-7610.2012.02608.x

Cicchetti, D., \& Doyle, C. (2016). Child maltreatment, attachment and psychopathology: mediating relations. World Psychiatry, 15, 89-90. doi: 10.1002/wps.20337

Consejo Nacional de Adopciones de Guatemala (2008), Memoria de Labores del Consejo Nacional de Adopciones Guatemala 2008 (Report from the Activities of the Child Adoption Council, Guatemala). Retrieved from http://www.cna.gob.gt/MemoriaLabores Council of Europe (1950). European Convention for the Protection of Human Rights and Fundamental Freedoms, as amended by Protocols Nos. 11 and 14, 4 November 1950, ETS 5. Retrieved from: https://www.refworld.org/docid/3ae6b3b04.html Council of Europe (1967). European Convention of the Adoption of Children. European Treaty Series number 58. Retrieved from https://rm.coe.int/168006ff60

Cross, T. P. \& Hershkowitz, I. (2017). Psychology and child protection: Promoting widespread improvement in practice. Psychology, Public Policy, and Law, 23, 503-518. doi:10.1037/lae0000141

Cushing, G., Samuels, G., \& Kerman, B. (2014). Profiles of relational permanence at 22: Variability in parental supports and outcomes among young adults with foster care histories. Children \& Youth Services Review, 39, 73-83. doi:0.1016/j.childyouth.2014.01.001 
del Pozo de Bolger, A., Dunstan, d. \& Kaltner, M. (2017) Descriptive analysis of foster care adoptions in New South Wales, Australia. Australian Social Work, 70, 477-490. doi:10.1080/0312407X.2017.1335759

Department of Education (2018). Statistics: looked-after children. Retrieved from https:/www.gov.uk/government/collections/statistics-looked-after-children

Dibben, E., \& Howorth, V. (2017). The role of fostering for adoption in achieving early permanence for children. London: CoramBAAF.

Dozier, M., Grasso, D., Lindheim, O., \& Lewis, E. (2007). The role of caregiver commitment in foster care: Insights from the This Is My Baby Interview. In D. Oppenheim \& D. Goldsmith (Eds.), Attachment theory in clinical work with children: Bridging the gap between research and practice (pp. 90-108). New York: Guilford Press.

Dozier, M., Kaufman, J., Kobak, R., O'Connor, T. G., Sagi-Schwartz, A., Scott, S., ... Zeanah, C. H. (2014). Consensus statement on group care for children and adolescents: A statement of policy of the American Orthopsychiatric Association. American Journal of Orthopsychiatry, 84, 219-225. doi:10.1037/ort0000005

Doughty, J., Meakings, S., \& Shelton, K. (2019) Rights and relationships of children who are adopted from care. International Journal of Law, Policy and the Family, 33, 1-23 doi:10.1093/lawfam/eby016

Dunbar, N., \& Grotevant, H. D. (2004). Adoption narratives: The construction of adoptive identity during adolescence. In M. W. Pratt \& B. H. Fiese (Eds.), Family Stories and the Life Course: Across Time and Generations (pp. 135-161). Mahwah, NJ: Erlbaum. 
Eurochild (2017). Opening doors for Europe’s children. Ending the era of institutional care in Europe. Brussels: Eurochild. Retrieved from http://www.openingdoors.eu/wpcontent/uploads/2017/06/OD-call-to-action-02062017.pdf

European Society of Human Reproduction and Embryology (2018). Focus on reproduction. January 2018. Grimbergen, Belgium: ESHRE.

Farmer, E. (2018). Reunification from out-of-home care. A research overview of good practice in returning children home from care. Bristol: University of Bristol.

Farmer, E. \& Dance, C. (2016). Family finding and matching in adoption: What helps to make a good match? The British Journal of Social Work, 46, 974-992. doi:10.1093/bjsw/bcv003

Farr, R. H., \& Patterson, C. J. (2013). Coparenting among lesbian, gay, and heterosexual couples: Associations with adopted children’s outcomes. Child Development, 84, 1226 1240. doi:10.1111/cdev.12046

Feast, J., Grant, M., Rushton, A., Simmonds, J., \& Sampeys, C. (2013). Adversity, adoption and afterwards: A mid-life follow-up study of women adopted from Hong Kong. London: BAAF.

Fein, E., \& Maluccio, A. (1992), Permanency planning: another remedy in jeopardy? Social Service Review, 66, 335-348.

Fenton-Glynn, C. (2015). Adoption without consent. Study for the Peti Committee. Brussels: European Parliament. Retrieved from: http://www.europarl.europa.eu/RegData/etudes/STUD/2015/519236/IPOL_STU(2015)51 9236_EN.pdf 
Fernandez, E., \& Lee, J.-S. (2013). Accomplishing family reunification for children in care: An Australian study. Children and Youth Services Review, 35, 1374-1384. doi:10.1016/j.childyouth.2013.05.006

Ferrari, L., Rosnati, R., Canzi, E., Ballerini, A., \& Ranieri, S. (2017). How international transracial adoptees and immigrants cope with discrimination? The moderating role of ethnic identity in the relation between perceived discrimination and psychological wellbeing. Community \& Applied Psychology, 27, 437-449. doi:10.1002/casp.2325

Gibbons, J., Conroy, S., \& Bell, C. (1995). Operating the child protection system. A study of child protection practices in English Local Authorities. London: HMSO.

Gilbert, N., Parton, N., \& Skivenes, M. (2011). Child protection systems: International trends and orientations. New York, NY: Oxford University Press.

Golombok, S. (2015). Modern families. Parents and children in new family forms. Cambridge, UK: Cambridge University Press.

Grotevant, H. D., Lo, A. Y. H., Fiorenzo, L., \& Dunbar, N. D. (2017). Adoptive identity and adjustment from adolescence to emerging adulthood: A person-centered approach. Developmental Psychology, 53, 2195-2204. doi:10.1037/dev0000352

Grotevant, H. D., Rueter, M., Von Korff, L. A., \& Gonzalez, C. (2011). Post-adoption contact, adoption communicative openness, and satisfaction with contact as predictors of externalizing behavior in adolescence and emerging adulthood. Journal of Child Psychology and Psychiatry, 52, 529-536. doi:10.1111/j.1469-7610.2010.02330.x

HCCH (1993). Convention of 29 May 1993 on Protection of children and cooperation in respect of intercountry adoption. Retrieved from: https://www.hcch.net/en/instruments/conventions/full-text/?cid=69 
HCCH (2008). The implementation and operation of the 1993 Hague Intercountry Adoption Convention. Guide to good practice 1. Bristol: Jordan Publishing Ltd.

HCCH (2012). The implementation and operation of the 1993 Hague Intercountry Adoption Convention. Guide to good practice 2. Bristol: Jordan Publishing Ltd.

HCCH (2015a). 20 years of the 1993 Hague Convention: Assessing the impact of the convention on laws and practices relating to intercountry adoption and the protection of children. Retrieved from https://assets.hcch.net/docs/ccbf557d-d5d2-436d-88d6-90cddbe78262.pdf HCCH (2015b). The financial aspects of intercountry adoption. Retrieved from https://assets.hcch.net/upload/wop/factsheet_finasp_en.pdf

Hébert, S., Lanctôt, N., \& Turcotte, M. (2016). “I didn't want to be moved there”: Young women remembering their perceived sense of agency in the context of placement instability. Children and Youth Services Review, 70, 229-237. doi:10.1016/j.childyouth.2016.09.029

Helder, E.J., Mulder, E., \& Gunnoe, M.L. (2014). A longitudinal investigation of children adopted internationally at school age. Child Neuropsychology, 22, 39-64. doi:10.1080/09297049.2014.967669

Hellerstedt, W.L., Madsen, N.J., Gunnar, M.R., Grotevant, H.D., Lee, R.M., \& Johnson, D.E. (2008). The International Adoption Project: Population-based Surveillance of Minnesota Parents Who Adopted Children Internationally. Maternal and Child Health, 12, 162-171. doi:10.1007/s10995-007-0237-9

Hjern, A., Vinnerljung, B., \& Brännström, L. (in press). Outcomes in adulthood of adoption after long-term foster care: A sibling study. Developmental Child Welfare. 
James, S., Landsverk, J., Slymen, D. J., \& Leslie, L. K. (2004). Predictors of outpatient mental health service use- the role of foster care placement change. Mental Health Services Research, 6, 127-141. doi:10.1023/B:MHSR.0000036487.39001.51

Johnson, D. E. (2000). Medical and developmental sequelae of early childhood institutionalization in Eastern European adoptees. In C. A. Nelson (Ed.), The effects of early adversity on neurobehavioral development: The Minnesota Symposia on Child Psychology (pp. 113-162). Mahwaw, NJ: Lawrence Erlbaum Associates.

Johnson, D. E., \& Gunnar, M. R. (2011). Growth failure in institutionalized children. Monographs of the Society for Research on Child Development, 76, 92-126. doi:10.1111/j.1540-5834.2011.00629.x

Johnson, D. E., Guthrie, D., Smyke, A. T., Koga, S. F., Fox, N. A., Zeanah, C. H., \& Nelson, C. A. (2010). Growth and associations between auxology, caregiving environment, and cognition in socially deprived Romanian children randomized to foster vs ongoing institutional care. Archives of Pediatric and Adolescent Medicine, 164, 507-516. doi:10.1001/archpediatrics.2010.56

Johnson, D.E., Tang, A., Almas, A.N., Degnan, K.A., McLaughlin, K.A., Nelson, C.A., Fox, N.A., Zeanah, Ch., \& Drury, S.S. (2018) Caregiving disruptions affect growth and pubertal development in early adolescence in institutionalized and fostered Romanian children: A randomized clinical trial. The Journal of Pediatrics, 203, 345-353.e3. doi:10.1016/j.jpeds.2018.07.027

Jones, J. \& Placek, P. (2017). Adoption by the numbers. Alexandria, VA: National Council for Adoption. 
Juffer F., \& Bakermans-Kranenburg, M.J. (2018). Working with Video-feedback Intervention to promote Positive Parenting and Sensitive Discipline (VIPP-SD): A case study. Journal of Clinical Psychology, 74, 1346-1357. doi.org/10.1002/jclp.22645

Juffer, F., \& Van IJzendoorn, M.H. (2005). Behavior problems and mental health referrals of international adoptees: A meta-analysis. JAMA: The Journal of the American Medical Association, 293, 2501-2515. doi:10.1001/jama.293.20.2501

Juffer, F., \& Van IJzendoorn, M.H. (2007). Adoptees do not lack self-esteem: A meta-analysis of studies on self-esteem of transracial, international, and domestic adoptees. Psychological Bulletin, 133, 1067-1083. doi:10.1037/0033-2909.133.6.1067

Jurviste, U., Sabbati, G., Shreeves, R., \& Dimitrova-Stul, A. (2016). Adoption of children in the European Union. Briefing. European Union: European Parlamentary Research Service.

Kahan, M. (2006). 'Put up’ on platforms: A history of Twenty Century adoption policy in the United States. The Journal of Sociology and Social Welfare, 33, 51-72.

Kavanaugh, B. C., Dupont-Frechette, J. A., Jerskey, B. A., \& Holler, K. A. (2017). Neurocognitive deficits in children and adolescents following maltreatment: Neurodevelopmental consequences and neuropsychological implications of traumatic stress, Applied Neuropsychology: Child, 6, 6478. doi:10.1080/21622965.2015.1079712

Lionetti, F., Pastore, M., \& Barone, L. (2015). Attachment in institutionalized children: A review and meta-analysis. Child Abuse \& Neglect, 42, 135-145. doi:10.1016/j.chiabu.2015.02.013

McGinnis, H. A., Baden, A. L, Kim, A. Y., \& Kim, J. R. (2019). Generational shifts: Adult adoptee scholars’ perspective on future research and practice. Rudd Adoption Research Program Publication Series: The Future of Adoption. Amherst, MA: University of Massachusetts Amherst. 
Melero, S., \& Sánchez-Sandoval, Y. (2017). Mental health and psychological adjustment in adults who were adopted during their childhood: A systematic review. Children and Youth Services Review, 77, 188-196. doi:10.1016/j.childyouth.2017.05.006

Milan, S. E., \& Pinderhughes, E. E. (2000). Factors influencing maltreated children's early adjustment in foster care. Developmental Psychopathology, 12, 63-

81. doi:10.1017/S0954579400001048

Ministry of Social Affairs of the People’s Republic of China (2018). Adoption. Retrieved from www.mca.gov.cn

Ministry of Education and Science of the Russian Federation (2015). Usynovlenie v Rossii (Adoption in Rusia). Retrieved from http://www.usynovite.ru/statistics/2015/

Nanni, V., Uher, R., \& Danese, A. (2012). Childhood maltreatment predicts unfavorable course of illness and treatment outcome in depression: A meta-analysis. American Journal of Psychiatry, 169, 141-151. doi:10.1176/appi.ajp.2011.11020335

Newton, R. R., Litrownik, A. J., \& Landsverk, J. A. (2000). Children and youth in foster care: Disentangling the relationship between problem behaviors and number of placements. Child Abuse and Neglect, 24, 1363-1374. doi:10.1016/S0145-2134(00)00189-7

Palacios, J., Rolock, N., Selwyn J., \& Barbosa-Ducharne, M. (2019). Adoption breakdown: Concept, research and implications. Research on Social Work Practice, 29, 130-142. doi:10.1177/1049731518783852

Palacios, J., Román, M., Moreno, C., León, E., \& Peñarrubia, M. (2014). Differential plasticity in the recovery of adopted children after early adversity. Child Development Perspectives, 8, 169-174. doi:10.1111/cdep.12083 
Petersen, A.C., Joseph, J. \& Feit, M. (Ed.) (2014). New directions in child abuse and neglect research. Washington, DC: Institute of Medicine and National Research Council.

Pinderhughes, E. E., Matthews, J.A.K., \& Zhang, X. (2016). Ethnic identity formation. In R. Fong \& R. McRoy (Eds.), Transracial and intercountry adoptions: Cultural guidance for professionals (pp. 154-192). New York: Columbia University Press.

Pollak, S. D., Nelson, C. A., Schlaak, M., Roeber B., Wewerka S., Wiik K. L., Frenn K.A., Loman M. M., \& Gunnar, M. R. (2010). Neurodevelopmental effects of early deprivation in post-institutionalized children. Child Development, 81, 224-236. doi:10.1111/j.1467624.2009.01391.x.

Purvis, K. B., Razuri, E. B., Hiles Howard, A. L., Call, D. C., DeLuna, J. H., Hall, J. S., \& Cross, D. R. (2015). Decrease in behavioral problems and trauma symptoms among at-risk adopted children following trauma-informed parent training intervention. Journal of Child \& Adolescent Trauma, 8, 201-210. doi:10.1007/s40653-015-0055-y

Quality Improvement Center for Adoption and Guardianship Support and Preservation (2019). QIC-AG. Retrieved from https://qic-ag.org/

Raby, K. L., \& Dozier, M. (2018). Attachment across the lifespan: Insights from adoptive families. Current Opinion in Psychology, 25, 81-85. doi:10.1016/j.copsyc.2018.03.011

Rebbe, R., Nurius, P. S., Ahrens, K. R., \& Courtney, M. E. (2017). Adverse childhood experiences among youth aging out of foster care: A latent class analysis. Children and Youth Services Review, 74, 108-116. doi:10.1016/j.childyouth.2017.02.004

Rolock, N., \& White, K. R. (2016). Post-permanency discontinuity: A longitudinal examination of outcomes for foster youth after adoption or guardianship. Children and Youth Services Review, 70, 419-427. doi:10.1016/j.childyouth.2016.10.025 
Rosnati, R. (2005). The construction of adoptive parenthood and filiation in Italian families with adolescents: A family perspective. In D. M. Brodzinsky \& J. Palacios (Eds.), Psychological issues in adoption: Research and practice (pp. 187-209). Westport, CT: Praeger.

Rubin, D. M., O’Reilly, A. L. R., Luan, X., \& Localio, A. R. (2007). The impact of placement instability on behavioral wellbeing for children in foster care. Pediatrics, 119, 39-58. doi:10.1542/peds.2006-1995

Rushton, A., Grant, M., Feast, J., \& Simmonds, J. (2013). The British Chinese adoption study: orphanage care, adoption and mid-life outcomes. Journal of Child Psychology and Psychiatry, 54, 1215-1222. doi:10.1111/jcpp.12088

Ryan, J.P., Hernandez, P.M. \& Herz, D. (2007). Developmental trajectories of offending for male adolescents leaving foster care. Social Work Research, 31, 8393. doi:10.1093/swr/31.2.83

Scherman, R., Misca, G., Rotabi, K., \& Selman, P. (2016). Global commercial surrogacy and international adoption: Parallels and differences. Adoption \& Fostering, 40, 20-35. doi: $10.1177 / 0308575915626376$

Schofield, G., \& Beek, M. (2018). Attachment handbook for foster care and adoption. London: CoramBAAF.

Selman, P. (2009). From Bucharest to Beijing: Changes in countries sending children for international adoption 1990 to 2006. In G. M. Wrobel \& E. Neil (Eds.), International advances in adoption research for practice (pp. 41-69). New York: Wiley.

Smith, S.L. (2014). Keeping the promise: The case for adoption support and preservation. New York: Donaldson Adoption Institute. 
Schoenmaker C., Juffer F., Van IJzendoorn M.H., Van den Dries L., Linting M., Van der Voort A. \& Bakermans-Kranenburg M.J. (2015). Cognitive and health-related outcomes after exposure to early malnutrition: The Leiden longitudinal study of international adoptees. Children and Youth Services Review, 48, 80-86.

doi:10.1016/j.childyouth.2014.12.010

Sonuga-Barke, E.J.S., Kennedy, M., Kumsta, R., Knights, N., Golm, D., Rutter, M., Maughan, B., Schlotz, W., \& Kreppner, J. (2017). Child-to-adult neurodevelopmental and mental health trajectories after early life deprivation: the young adult follow-up of the longitudinal English and Romanian Adoptees study. Lancet, 389, 1539-1548. doi:10.1016/S0140-6736(17)30045-4

Stein, M. (2006). Young people leaving care. Child and Family Social Work, 11, 273279. doi:10.1111/j.1365-2206.2006.00439.x

Stott, T., \& Gustavsson, N. (2010). Balancing permanency and stability for youth in foster care. Children and Youth Services Review, 32, 619-625. doi:10.1016/j.childyouth.2009.12.009

Teicher, M. H., \& Samson, J. A. (2016). Annual research review: Enduring neurobiological effects of childhood abuse and neglect. Journal of Child Psychology and Psychiatry, 57, 241-266. doi: 10.1111/jcpp.12507

Ter Meulen, G., Smeets, D., \& Juffer, F. (in press). Feelings about relinquishment and adoption of adult intercountry adoptees are strongly related to their satisfaction with life. Adoption \& Fostering.

Tieman, W., van der Ende, J., \& Verhulst, F. C. (2005). Psychiatric disorders in young adult intercountry adoptees: An epidemiological study. American Journal of Psychiatry, 162, 592-598. doi:10.1176/appi.ajp.162.3.592 
Tieman, W., Van der Ende, J., \& Verhulst, F. C. (2008). Young adult international adoptees’ search for birth parents. Journal of Family Psychology, 22, 678-687. doi:10.1037/a0013172

TransMonEE (2015). Russian Federation country data. Retrieved from http:/transmonee.org/country/russian-federation/

Triseliotis, J., Feast, J., \& Kyle, F. (2005). The adoption triangle revisited: A study of adoption, search and reunion experiences. London: BAAF.

United Nations General Assembly (1989). Convention on the Rights of the Child, 20 November 1989. United Nations, Treaty Series, vol. 1577, p. 3, Retrieved from: https://www.refworld.org/docid/3ae6b38f0.html

United Nations General Assembly (2010). Guidelines for the Alternative Care of Children: Resolution. Adopted by the General Assembly, A/RES/64/142, Retrieved from http://www.refworld.org/docid/4c3acd162.htm

United Nations Population Divison (2009). Child adoption: Trends and policies. New York: United Nations.

US Children’s Bureau. (2016). Adoption data 2014. Washington, DC: Administration for Children and Families.

Van den Dries, L., Juffer, F., Van IJzendoorn, M.H. \& Bakermans-Kranenburg, M. (2009). Fostering security? A meta-analysis of attachment in adopted children. Children and Youth Services Review, 31, 410-421. doi: 10.1016/j.childyouth.2008.09.008

Van Ginkel, J. R., Juffer, F., Bakermans-Kranenburg, M. J., \& van IJzendoorn, M. H. (2016). Do internationally adopted children in the Netherlands use more medication than their non- 
adopted peers? European Journal of Pediatrics, 175, 715-725. doi:10.1007/s00431-0162697-7

Van Ginkel, J., Juffer, F., Bakermans-Kranenburg, M.J., \& Van IJzendoorn, M.H. (2018). Young offenders caught in the act: A population-based cohort study comparing internationally adopted and non-adopted adolescents. Children and Youth Services Review, 95, 32-41. doi:10.1016/j.childyouth.2018.10.009

Van IJzendoorn, M.H., Bakermans-Kranenburg, M.J., Duschinsky, R., \& Skinner, G.C.M. (in press). Legislation in search of 'good-enough' care arrangements for the child: A quest for continuity of care. In J.G. Dwyer (Ed.), Oxford Handbook of children and the law. Oxford, UK: Oxford University Press.

Van IJzendoorn, M. H., Bakermans-Kranenburg, M. J., \& Juffer, F. (2007). Plasticity of growth in height, weight, and head circumference: meta-analytic evidence of massive catch-up after international adoption. Journal of Developmental and Behavioral Pediatrics, 28, 334-343. doi:10.1097/DBP.0b013e31811320aa

Van IJzendoorn, M.H. \& Juffer, F. (2006). The Emanuel Miller Memorial Lecture 2006: Adoption as intervention. Meta-analytic evidence of massive catch-up and plasticity in physical, socio-emotional, and cognitive development. Journal of Child Psychology and Psychiatry, 47, 1228-1245. doi:10.1111/j.1469-7610.2006.01675.x

Van IJzendoorn, M.H., Juffer, F., \& Klein Poelhuis, C.W. (2005). Adoption and cognitive development: A meta-analytic comparison of adopted and non-adopted children's IQ and school performance. Psychological Bulletin, 131, 301-316. doi:10.1037/00332909.131.2.301 
Van IJzendoorn, M. H., Luijk, M. P. C. M., \& Juffer, F. (2008). IQ of children growing up in children's homes: A meta-analysis on IQ delays in orphanages. Merrill-Palmer Quarterly, 54, 341-366. doi:10.1353/mpq.0.0002

Van IJzendoorn, M. H., Palacios, J., Sonuga-Barke, E. J., Gunnar, M. R., Vorria, P., McCall, R. B., .. . Juffer, F. (2011). Children in institutional care: Delayed development and resilience. Monographs of the Society for Research on Child Development, 76, 8-30. doi:10.1111/j.1540-5834.2011.00626.x

Vinnerljung, B. \& Hjern, A. (2011). Cognitive, educational and self-support outcomes of longterm foster care versus adoption. A Swedish national cohort study. Children and Youth Services Review, 33, 1902-1910. doi: 10.1016/j.childyouth.2011.05.016

Woodhouse, S., Miah, A., \& Rutter, M. (2018). A new look at the supposed risks of early institutional rearing. Psychological Medicine, 48, 1-10. doi:10.1017/s0033291717001507

Wrobel, G. M., \& Dillon, K. (2009). Adopted adolescents: Who and what are they curious about? In G. M. Wrobel and E. Neil (Eds.) International advances in adoption research for practice (pp. 217-244). London: Wiley.

Wrobel, G.M., \& Grotevant, H.D. (2019). Adoption-related curiosity at emerging adulthood. Adoption Quarterly. Advanced online publication.

Wrobel, G. M., Grotevant, H. G., Samek, D. R., \& Von Korff, L. (2013) Adoptees’ curiosity and information-seeking about birth parents in emerging adulthood: Context, motivation, and behavior. International Journal of Behavioral Development, 37, 441-450. doi:10.1177/0165025413486420 
Zeanah, C. H., \& Gleason, M. M. (2015). Annual research review: Attachment disorders in early childhood —clinical presentation, causes, correlates, and treatment. Journal of Child Psychology and Psychiatry, 56, 207-222. doi:10.1111/jcpp.12347 